\title{
Turkish Seaborne Trade and the Effects of the Strategic Developments in the International Energy and Transport Corridors: A Qualitative Research*
}

\author{
Barış KULEYINN ${ }^{1}$, Ayșe Güldem CERİT ${ }^{1}$ \\ ${ }^{1}$ Dokuz Eylul University, Maritime Faculty, Turkey, baris.kuleyin@deu.edu.tr; gcerit@deu.edu.tr
}

\begin{abstract}
The facts that strong economies require more energy production which in turn requires further energy resources increase the importance of the energy and transport corridors for energy policies. This increase makes it clear that sea transport has a strategic role in terms of transit passage and the port/terminal links of pipelines. Concerning all these interrelations, this exploratory research aims to explore and reveal the effects of the strategic developments focused on the international energy and transport corridors on the Turkish seaborne trade. To reach this particular aim, a through literature review was carried out concerning the international energy and transport corridors and international energy sector. This literature review was followed by certain content analysis regarding the effects of the developments in the above mentioned areas on Turkey in general and a Delphi research involving the effects of such developments on the Turkish seaborne trade in particular. The research was concluded with a discussion on the statements agreed during Delphi research process. The discussion created certain recommendations and revealed that Turkey can maintain and sustain her effectiveness on the international energy and transport corridors only and only through having a powerful and effective seaborne trade structure.
\end{abstract}

Keywords: Energy and Transport Corridors, Turkish Seaborne Trade, Geostrategy, Energy Strategy.

\section{Uluslararası Enerji ve Ulaştırma Koridorlarındaki Stratejik Gelişmelerin Türk Deniz Ticaretine Etkisi Üzerine Nitel Bir Araştırma*}

$\ddot{O} z$

Güçlü bir ekonomi için daha fazla enerji üretmeye ve daha fazla enerji üretebilmek için ise daha çok enerji kaynağına ihtiyaç duyulması; enerji ve ulaştırma koridorlarının enerji politikalarındaki önemini arttırmaktadır. Söz konusu süreçte, denizyolu taşımacılığı; transit geçişler ve boru hatlarının liman/terminal bağlantıları açısından stratejik bir öneme sahiptir. Bu bilgiler ıșığında, uluslararası enerji ve ulaştırma koridorları üzerinde odaklanan stratejik gelişmelerin Türk deniz ticaretine etkilerinin saptanmasına katkıda bulunmak amacıyla keșifsel nitelikli bir araștırma yapılması amaçlanmıștır. Uluslararası enerji ve ulaștırma koridorları ile uluslararası enerji sektörü kapsamında yapılan literatür taraması sonucunda, söz konusu alanlarda meydana gelen stratejik gelișmelerin, Türkiye’ye yansımasına ilişkin içerik analizleri yapılmış; daha sonra, bu gelişmelerin, Türk deniz ticaretine etkisi üzerine bir delfi araştırması gerçekleștirilmiştir. Çalışmanın sonuçlar bölümünde Delfi araştırmasında uzlaşılan ifadeler tartışılmışv ve bu ifadeler çerçevesinde öneriler geliștirilmiştir. Bu bulgulardan yola çıkllarak, Türkiye'nin uluslararası enerji ve ulaştırma koridorlarındaki etkinliğini ancak güçlü bir deniz ticareti yapısıyla gerçekleștirebileceği ortaya koyulmuştur.

Anahtar Kelimeler: Enerji ve Ulaștırma Koridorlarl, Türk Deniz Ticareti, Jeostrateji, Enerji Stratejisi.

* This study was presented at the "Second International Congress on Energy Security in Southeast Europe" had been held in Izmir - Turkey between 06-08 November 2014. 


\section{Introduction}

There is a strong relationship between the demands for energy and the economic growth particularly in the developing countries. The more industrialization in these countries the more energy consumption [1, 2, 3, 4]. Although recently increased environmental awareness and the efforts made to save the earth from the "bad man" fossil fuels cannot be undermined, no renewable energy source is expected to win the competition against oil and natural gas in terms of trade scale for at least 30 or 40 years in the near future [5]. The developed countries meet a great part of their demands for energy through oil and natural gas respectively. The developing countries, however, use coal to a high extent [6]. The world coal reserves said to be available for 126 years, however, do not have a strategic position as dependable as does oil and natural gas [7, 6].

Owning oil and natural gas resources, keeping its production in hand and energy corridors under control have been the main aim of the developed countries. In connection with this fact, beyond many socio-political events lay the struggles to keep the energy resources under control [8]. The involvement of oil, natural gas and coal in shipping activities is of great importance and the electrical centrals recently installed on ships has raised this importance to even a higher extent [9].

Keeping all such developments in mind, this study aims to carry out a discovery research involving both qualitative and quantitative aspects so as to find out the effects of the recent strategically developments regarding the international energy and transport corridors on Turkish seaborne trade.

\section{Methodology}

Qualitative researches focus on a specific subject and composed of several techniques they bring forward an approach to the research problem involving certain viewpoints and/or interpretations [10]. Although it is rather difficult to the reach a clear-cut definition of qualitative research method including all the processes methods, approaches and specifications, it could roughly be defined as a sequence of process which involves revealing certain perceptions, and incidents in a realistic and holistic manner in a natural environment in which qualitative data collection tools such as observation, interviewing and document analyses are used [11]. In this study, "Delphi technique", a strong qualitative research method $[12,13]$ has been used. The reason why Delphi technique has been preferred is because it enables certain experts in maritime issues and energy related topics to pore over these subjects and put forward delinked explorations and many sides' interpretations and viewpoints.

The literature offers various definitions for Delphi technique [14]. One of there is offered by Linstone ve Turoff (1975) as " $a$ method of forming a group communicating process involving individuals who discuss the means to overcome certain problems encountered" [15]. In other words, Delphi technique which is also known as an instrument used to reach certain compromise on a research problem, is a tool used to systematically collect the viewpoints of the experts specialized on the topic at hand [16]. This technique has various advantages over many other group decision techniques wherein it could be difficult to reach healthy decisions out of the face-to-face discussions made at panels composed of crowded panel members. One of the foremost advantages is that certain time and financial coast; emerging from gathering the panel members at certain time and place could be overcome [17].

Mullen (2003) states that [18] based on the types of practicing and methods of grading, there are 23 types of Delphi (classical, conventional, real-time Delphi 
etc.) and 20 types of Delphi practices (Delphi practices, Delphi technique, Delphi panel etc.) still, the most commonly used ones are categorized into three (classical Delphi, decision making Delphi and policy Delphi) $[19,20,14]$.

Policy Delphi is more commonly used in social sciences, social and political issues than classical Delphi. This Delphi type aims to reach alternative policies based on structured social dialogues [19]. The policy Delphi technique, used in maritime policies, logistics and transportation related policies $[21,22]$ is to reach any one or more of the following targets [23]:

- Put forward all likely options to be discussed and evaluated

- Calculate/approximate the effects and likely results of any option

- Calculate and scrutinize any likely appropriateness of any option

The steps to be followed in a policy Delphi are as follows; 1 . Determining the issue and defining the problem, 2 . Determining the required expertise, 3. Choosing the experts and forming a heterogenic group, 4. Preparing the initial Delphi questionnaire, 5. Analyzing the initial Delphi questionnaire, 6. If needed, applying a second tour Delphi questionnaire, 7. Analyzing the Delphi questionnaire and 8. Realizing a group meeting [19].

With the help of the data collected through a literature review, a model has been created where in the likely effects of the strategic developments regarding the energy and transport corridors on Turkish seaborne trade are defined. The overall consumptions of energy in Turkey as well as in the world point to the fact that the basic energy resources transported through the international energy and transport corridors are crude oil, natural gas and coal. An overall investigation reveals that the distribution of these energy resources is carried out through two such transport modes as "pipelines" and "shipping". As Gökkuş (2013: 3) points out, pipelines enable the construction of energy bridges. The present and/or projected ports linked through pipelines as well as crude oil, LNG tankers and coal carrying bulkers clearly define the close relationship between the mentioned corridors and seaborne trade. Besides, the recently built energy ships with floating electrical centrals installed on involve shipbuilding industry in this particular interrelationship [24].

Within the conceptual model developed in this research, a thorough literature review and content analysis are involved. In accordance with the "statements" gained through such studies, a policy Delphi type research has been developed. And the result of the research based on the data collected has accompanied certain recommendations. The literature review in connection with the conceptual model has led to a great deal of sources. These sources have been exploited to carry out a content analysis with the aim of finding out (determining) the basic variables for the realized or likely strategic developments regarding the transport corridors particularly involving Turkey.

The literature review concerning the effects of the strategic developments of the international energy and transport corridors on Turkey has comprised 31 articles, books and reports. The content analysis carried out through the sources reviewed has concluded in 52 variables repeated in various frequencies. The frequency valves and distribution of these variables are detailed in Appendix 1. The top ten variables with the highest frequencies and their frequencies are indicated in Table 1 [25-53].

In addition to the variables listed in Table 1, the researches reviewed are seen 
Table 1. The Most Frequently Repeated Variables Revealed by the Content Analysis Involving the Effects of the Strategic Development Regarding the International Energy and Transport Corridors on Turkey

\begin{tabular}{|c|l|c|}
\hline No & The most frequently repeated variables & Frequency \\
\hline 1 & The importance of Turkey in terms of the safety of energy supply & 20 \\
\hline 2 & Turkey as an energy transit point & 18 \\
\hline 3 & Differentiations in energy transit corridors & 16 \\
\hline 4 & Triggering new investments & 15 \\
\hline 5 & Relatively cheaper and lower risky shipping & 14 \\
\hline 6 & Environmental and security concerns involving Turkish straits & 13 \\
\hline 7 & The roles of ports in energy transport & 13 \\
\hline 8 & Ceyhan Terminal as one of the leading world oil markets & 12 \\
\hline 9 & BTC crude oil pipeline as the most critical aspect of East-West energy corridor & 12 \\
\hline 10 & Ceyhan as an important energy terminal & 12 \\
\hline
\end{tabular}

Source: Authors

to the focused on such relevant subjects as the increase in tanker traffic through the Turkish straits, the convenient weather and port conditions, energy distribution centers/terminals, Ceyhan Region as an integrated energy center and lower shipping costs.

In this study, based on the variables formed as a result of the content analysis regarding the reflections of strategic developments having appeared at the international energy and transportation corridors, the following three steps have been planned; 1 . Determining the statements of the Delphi research to be used, 2. Determining the Delphi experts, and 3. Implementing the Delphi research.

\subsection{Determining the Statements to be Used in the Delphi Research}

The specifications of the Delphi statements collected from the relevant literature [54] are categorized into four general rules as follows [14]:

- There should be no ambiguity in the statements.

- The statement should be having no if clauses interconnected. Such case, different/indented clauses should be used.

- The scientific, academic and technological terms should be accurate and comprehensible.

- All variables should have clear verified definitions.

In compliance with the above mentioned points the Delphi statements should have no emotional aspects or any groups of emotional words [55]. Another point to be considered is the length of the Delphi questionnaire. Some scholars think that the Delphi questionnaire should be limited up to 25 statements at most so as to increase the ratio of responses and receive satisfactory responses [14].

The statements to be used in Delphi research have been categorized into such three groups as economic effects, political effects, and safety/security effects in connection with the research model developed taking into consideration the content analysis as well as the socioeconomic risks involved in the crude oil and natural gas energy corridors. A total of 19 Delphi statements are indicated in Table 2 . 
Table 2. Delphi Statements Involving the Effects of the Strategic Developments Regarding the International Energy and Transport Corridors or Turkish Seaborne Trade

\begin{tabular}{|c|c|}
\hline A. & ECONOMIC EFFECTS \\
\hline 1 & $\begin{array}{l}\text { With the big tonnages of tanker shipments at her ports, Turkey will play a critical role in the world } \\
\text { tanker market. }\end{array}$ \\
\hline 2 & $\begin{array}{l}\text { The crude oil transported through pipelines in Turkey to the world markets has been an investment- } \\
\text { triggering point for Turkish shipping. }\end{array}$ \\
\hline 3 & $\begin{array}{l}\text { In the transport of crude oil from Mid Asia and Mid East to the world markets, Turkey gains a } \\
\text { considerable income through the port services like warehousing and shipment activities, ship mooring, } \\
\text { shipment supervising and all kinds of business related processes and maintenance operations. }\end{array}$ \\
\hline 4 & $\begin{array}{l}\text { Baku-Tiflis-Ceyhan Pipeline, one of the most critical aspects of the East-West Energy Corridors, enables } \\
\text { the improvement of Turkish tanker shipping. }\end{array}$ \\
\hline 5 & $\begin{array}{l}\text { Due to the Samsun-Ceyhan By-Pass Oil Pipeline Project, Turkey has become one of the leading world } \\
\text { crude oil markets. }\end{array}$ \\
\hline 6 & $\begin{array}{l}\text { Crude oil transport through Turkey, relatively decreases the costs of transport from the Russian ports } \\
\text { along the Black Sea. }\end{array}$ \\
\hline 7 & $\begin{array}{l}\text { The increase in the handling capacity of the Marmara Eregli and Ege Gas LNG Terminals has enabled the } \\
\text { Turkish LNG tanker operations to improve to a further extent. }\end{array}$ \\
\hline 8 & $\begin{array}{l}\text { Establishment of LNG terminals in Turkey would encourage the Turkish shipping and ship building } \\
\text { industries to get interested in LNG shipping. }\end{array}$ \\
\hline 9 & $\begin{array}{l}\text { Installment of electrical centers on Energy ships would contribute to the improvement of the Turkish } \\
\text { ship yards. }\end{array}$ \\
\hline 10 & $\begin{array}{l}\text { Increase in the share of coal in the Turkish energy production would enable the Turkish bunker fleet to } \\
\text { improve to a further extent. }\end{array}$ \\
\hline B. & POLITICAL EFFECTS \\
\hline 1 & $\begin{array}{l}\text { Ceyhan Region, with an important place within the regions; plays an important role in setting the energy } \\
\text { policies of Turkey. }\end{array}$ \\
\hline 2 & $\begin{array}{l}\text { Establishing refineries in the Mediterranean Region with crude oil processing capacities would make } \\
\text { Turkey a key-point in this respect. }\end{array}$ \\
\hline 3 & $\begin{array}{l}\text { With the further investments in ports and transport infrastructure Turkey would turn Ceyhan Terminal, } \\
\text { an exit gate for energy corridors; into one of the most important energy centers. }\end{array}$ \\
\hline 4 & It is possible for Turkey to turn Ceyhan Terminal into an energy center like Rotterdam Terminal. \\
\hline 5 & $\begin{array}{l}\text { When Samsun-Ceyhan crude oil Pipeline Projects is realized, Samsun Port would have a strategic } \\
\text { importance in terms of energy transport. }\end{array}$ \\
\hline C. & SECURITY/SAFETY EFFECTS \\
\hline 1 & There is a terror risk in Ceyhan Region in terms of energy supply. \\
\hline 2 & $\begin{array}{l}\text { An increase in the number of the big tonnage tankers being loaded at Ceyhan Region increases the risk of } \\
\text { the Turkish coasts along the Mediterranean Sea to get exposed to oil pollution. }\end{array}$ \\
\hline 3 & $\begin{array}{l}\text { Through Baku-Tiflis-Ceyhan crude oil pipeline, the passage related risks caused by the excessive (heavy) } \\
\text { tanker traffic through the Turkish Straits are minimized. }\end{array}$ \\
\hline 4 & $\begin{array}{l}\text { The increase in the number of the LNG tankers approaching (calling) Marmara Eregli and Ege Gas LNG } \\
\text { Terminals increases the safety risks at the terminals. }\end{array}$ \\
\hline
\end{tabular}

Source: Developed by the authors. 


\subsection{Selecting the Experts to Get Involved in Delphi Research}

For the effectiveness of any Delphi research, determining the experts is a very important factor $[56,57]$. The experts to get involved in Delphi research are to be well-knowledge and experienced in the topics in question, willing to participate in the research, able to spare time for Delphi practices and have well communicative skills [14]. Analyzing some of the researches that have used Delphi reveals that there are various numbers offered for the body of the panel $[58,59]$. The policy delphies are recommended to have 10 to 50 members [60]. Besides, the homogenic or heterogenic structures of the panel are another point of discussion. In policy delphies, for instance, the panel is said to be heterogenic so as to determine diverse points of discussion [14].

A group of 22 experts has been formed who are thought to interpreted and discuss the Delphi statements detailed in Table 2. While forming the expert group, involving therepresentativesfrom thetopicsas Safety/ Security Related Sea Environment, Energy and Maritime Policies, Pipelines, Turkish Seaborne Trade, Shipping and Investment has been taken into consideration. Keeping these topics in mind, 11 experts from the top managers of such state institutions as Ministry of Transport, Maritime Affairs and Communications (UDHB), Ministry of Development (DPT), General Directorate of Infrastructure Investments (DLH), Petroleum Pipeline Corporation (BOTAS) and Directorate General of Coastal Safety (KEGM), 1 tanker broker, 3 academics, and $7 \mathrm{mid} / \mathrm{up}$ managers seaborne trade have been selected. The names and their institutions have been kept confidential as per the requests of the experts involved in Delphi research.

\subsection{Implementation}

In implementing Delphi researches, likert scale is commonly used. The likert scale to be used is to include 3 points at least and 11 point at most [61]. In 3-point likert scale, three responses such as "I agree", "I disagree" and "No comment" are preferred [62, 63]. Another variable used in Delphi implementation is the number of the tours, which ranges from 1 to 10 [14]. In order for the sensitivity of the research to be acceptable, the most proper number of tours is considered to be the least/lowest number of tours. This number will vary depending upon the structure of the panel, the nature of the problem to be solved and the feedback received following each tour [64]. Although delphies usually consist of 3 tours, it is possible to see some one-tour round delphies, and the number of oneround delphies is thought to get increased in the future [65].

In approximating the compromise reached by the members of a panel, various methods are used [14]. In policy determining delphies with nominal-scale (3-point likert), for example a two-thirds level is considered to be "compromise". Therefore, if the approximated ratio of compromise for each statement $66,7 \%$ or higher, then it is thought that a compromise has been reached or the mentioned statement. The reason for the keeping of compromise so low is that the point of discussion is extremely political [21].

Despite various methods used in reaching an agreement [50]. In 3-point likert scale policy delphies, 2/3 compromised agreement is said to be satisfactory for reaching an agreement. So a $66,7 \%$ ratio of agreement, or over this ratio, for each statement would mean having reached an agreement. Such a low value agreement ratio items from the political nature of the statements discussed [14]. The Delphi questionnaire involving 19 statements formed in 3-point likert scale was e-mailed to the Delphi group individually on 28.12.2010 through 25.06.2011, having received their favorable reply through 
Table 3. The Agreement Rations for the Delphi the Statements Developed for the Effects of the Strategic Developments in the International Energy and Transport Corridors on Turkish Seaborne Trade

\begin{tabular}{|c|c|c|c|c|c|}
\hline \multirow{2}{*}{ No } & \multirow{2}{*}{ Delphi Statements } & \multicolumn{3}{|c|}{ Distribution* } & \multirow{2}{*}{ Results } \\
\hline & & $\mathbf{Y}$ & $\mathbf{N}$ & NC & \\
\hline 1 & $\begin{array}{l}\text { With the big tonnages of tanker shipments at her ports, Turkey will play a } \\
\text { critical role in the world tanker market }\end{array}$ & 8 & 12 & 2 & $\begin{array}{l}\% 60 \\
\text { I don't agree }\end{array}$ \\
\hline 2 & $\begin{array}{l}\text { The crude oil transported through pipelines in Turkey to the world markets has } \\
\text { been an investment-triggering point for Turkish shipping. }\end{array}$ & 14 & 7 & 1 & $\begin{array}{l}\% 66,7^{* *} \\
\text { I agree }\end{array}$ \\
\hline 3 & $\begin{array}{l}\text { In the transport of crude oil from Mid Asia and Mid East to the world markets, } \\
\text { Turkey gains a considerable income through the port services like warehousing } \\
\text { and shipment activities, ship mooring, shipment supervising and all kinds of } \\
\text { business related processes and maintenance operations. }\end{array}$ & 16 & 5 & 1 & $\begin{array}{l}\% 76,2^{* *} \\
\text { I agree }\end{array}$ \\
\hline 4 & $\begin{array}{l}\text { Baku-Tiflis-Ceyhan Pipeline, one of the most critical aspects of the East-West } \\
\text { Energy Corridors, enables the improvement of Turkish tanker shipping. }\end{array}$ & 8 & 13 & 1 & $\begin{array}{l}\% 61,9 \\
\text { I don't agree }\end{array}$ \\
\hline 5 & $\begin{array}{l}\text { Ceyhan Region, with an important place within the regions; plays an important } \\
\text { role in setting the energy policies of Turkey. }\end{array}$ & 17 & 5 & 0 & $\begin{array}{l}\% 77,3^{* *} \\
\text { I agree }\end{array}$ \\
\hline 6 & $\begin{array}{l}\text { Due to the Samsun-Ceyhan By-Pass Oil Pipeline Project, Turkey has become one } \\
\text { of the leading world crude oil markets. }\end{array}$ & 11 & 10 & 1 & $\begin{array}{l}\% 55 \\
\text { I agree }\end{array}$ \\
\hline 7 & $\begin{array}{l}\text { Through Baku-Tiflis-Ceyhan crude oil pipeline, the passage related risks caused } \\
\text { by the excessive (heavy) tanker traffic through the Turkish Straits are minimized. }\end{array}$ & 16 & 6 & 0 & $\begin{array}{l}\% 72,7^{* *} \\
\text { I agree }\end{array}$ \\
\hline 8 & $\begin{array}{l}\text { Crude oil transport through Turkey, relatively decreases the costs of transport } \\
\text { from the Russian ports along the Black Sea. }\end{array}$ & 13 & 4 & 5 & $\begin{array}{l}\% 76,5^{* *} \\
\text { I agree }\end{array}$ \\
\hline 9 & There is a terror risk in Ceyhan Region in terms of energy supply. & 5 & 13 & 4 & $\begin{array}{l}\% 72,2^{* *} \\
\text { I don't agree }\end{array}$ \\
\hline 10 & $\begin{array}{l}\text { Establishing refineries in the Mediterranean Region with crude oil processing } \\
\text { capacities would make Turkey a key-point in this respect. }\end{array}$ & 16 & 2 & 4 & $\begin{array}{l}\% 88,9 * * \\
\text { I agree }\end{array}$ \\
\hline 11 & $\begin{array}{l}\text { An increase in the number of the big tonnage tankers being loaded at Ceyhan } \\
\text { Region increases the risk of the Turkish coasts along the Mediterranean Sea to } \\
\text { get exposed to oil pollution. }\end{array}$ & 14 & 7 & 1 & $\begin{array}{l}\% 66,7^{* *} \\
\text { I agree }\end{array}$ \\
\hline 12 & $\begin{array}{l}\text { With the further investments in ports and transport infrastructure Turkey } \\
\text { would turn Ceyhan Terminal, an exit gate for energy corridors; into one of the } \\
\text { most important energy centers. }\end{array}$ & 15 & 6 & 1 & $\begin{array}{l}\% 71,4^{* *} \\
\text { I agree }\end{array}$ \\
\hline 13 & $\begin{array}{l}\text { It is possible for Turkey to turn Ceyhan Terminal into an energy center like } \\
\text { Rotterdam Terminal. }\end{array}$ & 15 & 5 & 2 & $\begin{array}{l}\% 75^{* *} \\
\text { I agree }\end{array}$ \\
\hline 14 & $\begin{array}{l}\text { When Samsun-Ceyhan crude oil Pipeline Projects is realized, Samsun Port } \\
\text { would have a strategic importance in terms of energy transport. }\end{array}$ & 16 & 4 & 2 & $\begin{array}{l}\% 80^{* *} \\
\text { I agree }\end{array}$ \\
\hline 15 & $\begin{array}{l}\text { The increase in the handling capacity of the Marmara Eregli and Ege Gas LNG } \\
\text { Terminals has enabled the Turkish LNG tanker operations to improve to a } \\
\text { further extent. }\end{array}$ & 11 & 9 & 2 & $\begin{array}{l}\% 55 \\
\text { I agree }\end{array}$ \\
\hline 16 & $\begin{array}{l}\text { The increase in the number of the LNG tankers approaching (calling) Marmara } \\
\text { Eregli and EgeGas LNG Terminals increases the safety risks at the terminals. }\end{array}$ & 9 & 11 & 2 & $\begin{array}{l}\% 55 \\
\text { I don't agree }\end{array}$ \\
\hline 17 & $\begin{array}{l}\text { Establishment of LNG terminals in Turkey would encourage the Turkish } \\
\text { shipping and ship building industries to get interested in LNG shipping. }\end{array}$ & 14 & 7 & 1 & $\begin{array}{l}\% 66,7^{* *} \\
\text { I agree }\end{array}$ \\
\hline 18 & $\begin{array}{l}\text { Installment of electrical centers on Energy ships would contribute to the } \\
\text { improvement of the Turkish ship yards. }\end{array}$ & 16 & 4 & 2 & $\begin{array}{l}\% 80^{* *} \\
\text { I agree }\end{array}$ \\
\hline 19 & $\begin{array}{l}\text { Increase in the share of coal in the Turkish energy production would enable the } \\
\text { Turkish bunker fleet to improve to a further extent. }\end{array}$ & 8 & 10 & 4 & $\begin{array}{c}\% 55,6 \\
\text { I don't agree }\end{array}$ \\
\hline
\end{tabular}

Source: Prepared by the author. * Y-Yes, N-No, NC-No Comments ${ }^{* *}$ The consensus statements. 
phone contacts: After having e-mailed the questionnaires, the panelists were frequently contacted through phone calls an 3-mail messages and a full participation was aimed. The results gained from the 22 participants on 19 statements reveal that 243 of 418 responses were "I agree", 139 were "I don't agree" and 36 were "no comments". The allocation of these results for each statement revealed that 13 of the 19 statements were agreed. As indicated in Table 3, the agreement ratios for each statement are respectively as follows; 10. $(\% 88,9)$, 14. (\% 80), 18. (\% 80), 5. (\% $77,3), 8 .(\% 76,5), 3 .(\% 76,2), 13 .(\% 75)$, 7. $(\% 72,7), 9 .(\% 72,2), 12 .(\% 71,4), 2 .(\%$ $66,7), 11 .(\% 66,7)$ and 17. (\% 66,7).

\section{Findings and Data Analysis}

The findings of the one-tour Delphi research are analyzed in such three basic topics as economic, political, and security/ safety related effects of the strategic developments regarding the international energy and transport corridors on Turkish seaborne trade.

\subsection{Economic Effects}

Out of 10 statements regarding the economic effects five statements have received an agreement from the Delphi panelists. These five statements are the agreement ratios for each are indicated in Table 4.

The panelists have agreed that the Powership (Energy Ships) [66] being built at İstanbul Tuzla and İzmit Gölcük Shipyards will contribute a lot to improvement of Turkish Shipyard Industry. The agreement ratio is $80 \%$ (statement 18). While two panelists have not commented on the issue, four panelists have disagreed. The rest of the panelists have stated their agreements and underlined that "the preliminary projects have contributed to the cumulating of knowledge-know how", "our shipyards have progressed on this knowledge", "this progress must be promoted", and "the samples in hand support this viewpoint".

The agreement ratio for statement 8 is $76,6 \%$. While 13 panelist have favored this statement, 5 of them have underlined such factors as "the lessened voyage-day", "the

Table 4. The Delphi Statements Agreed on Regarding the Economic Effects of the Strategic Developments in the International Energy and Transport Corridors on Turkish Seaborne

\begin{tabular}{|c|c|c|c|c|c|}
\hline \multirow{2}{*}{ No } & \multirow{2}{*}{ Delphi Statements } & \multicolumn{3}{|c|}{ Distribution* } & \multirow{2}{*}{ Results } \\
\hline & & $\mathbf{Y}$ & $\mathbf{N}$ & NC & \\
\hline 18 & $\begin{array}{l}\text { Installment of electrical centers on Energy ships would contribute to the } \\
\text { improvement of the Turkish ship yards. }\end{array}$ & 16 & 4 & 2 & $\begin{array}{l}\% 80^{* *} \\
\text { I agree }\end{array}$ \\
\hline 8 & $\begin{array}{l}\text { Crude oil transport through Turkey, relatively decreases the costs of transport } \\
\text { from the Russian ports along the Black Sea. }\end{array}$ & 13 & 4 & 5 & $\begin{array}{l}\% 76,5^{* *} \\
\text { I agree }\end{array}$ \\
\hline 3 & $\begin{array}{l}\text { In the transport of crude oil from Mid Asia and Mid East to the world markets, } \\
\text { Turkey gains a considerable income through the port services like warehousing } \\
\text { and shipment activities, ship mooring, shipment supervising and all kinds of } \\
\text { business related processes and maintenance operations. }\end{array}$ & 16 & 5 & 1 & $\begin{array}{l}\% 76,2^{* *} \\
\text { I agree }\end{array}$ \\
\hline 2 & $\begin{array}{l}\text { The crude oil transported through pipelines in Turkey to the world markets has } \\
\text { been an investment-triggering point for Turkish shipping. }\end{array}$ & 14 & 7 & 1 & $\begin{array}{l}\% 66,7^{* *} \\
\text { I agree }\end{array}$ \\
\hline 17 & $\begin{array}{l}\text { Establishment of LNG terminals in Turkey would encourage the Turkish } \\
\text { shipping and ship building industries to get interested in LNG shipping. }\end{array}$ & 14 & 7 & 1 & $\begin{array}{l}\% 66,7^{* *} \\
\text { I agree }\end{array}$ \\
\hline
\end{tabular}

Source: Prepared by the author.

* Y-Yes, N-No, NC-No Comments

${ }^{* *}$ The consensus statements. 
fees for passage through the Turkish Straits", "the waiting periods in winters while passing through the Turkish Straits", and "the likely advantages of the economies of scale". On the other hand, one of the panelists who have not agreed on the statement has underlined the points of "the inclinations towards increasing the fees for the passages through the Turkish Straits and strengthening the alternatives for the pipelines passing through Turkey".

The agreement ratio for statement 3 is $76,2 \%$. Some of the points put forward by those favoring the statement are "it should be investigated whether the revenues gained are satisfactory", "the basic term used in the statement is ambiguous", and "the revenue received is too little when compared with that of the world market". While 16 of the panelists have agreed on the statement, 5 of them have disagreed, and one has made no comments. Those have disagreed have underlined such points as "the revenue gained stays only around US \$10 million", and "the operations at BOTAS for example are under control of the foreigners, the payments to the Turkish companies are too little".

The ratio of agreement on statement 2 is $66,7 \%$; comprising 14 favorable and 7 unfavorable comments. Those who favored the statement have underlined such points as "triggering the new investments is restrained", "lack of refining and marketing powers", "Turkish owners' struggle for big tonnages of tanker fleets though inadequate yet", and "the completion of one of the $4 \mathrm{big}$ shipyards planned for Ceyhan free zone". On the other hand, those who have not favored the statement have focused on such points as "the triggered investment of British Petroleum (BP) only", "the ships involved are not Turkish flagged and under control of big oil companies", and "lack of certain regulations supporting the interests of Turkish shipping industry particularly within those regarding the multimodal transports passing through the end points of the pipelines".

The ratio of agreement on statement 17 is $66,7 \%$ comprising 14 agreements and 7 disagreements. Those who have agreed on the statement have underlined such factors as "the doubtful adequacy of the Turkish shipyards in LNG tanker building", "the principle of supply and demands", and "too costly LNG investments". Those who have disagreed have focused on such factors as "LNG building and management requires a high level of specialization", "the point involves freight markets", and "LNG trade is carried out based on ex-ship delivery terms".

The discussions over statements 1, 4, 15 and 19 reveal that these statements have not received any favorable responses.

\subsection{Political Effects}

All the five statements discussed by the panelists regarding the political effects have received favorable responses. These statements along with the agreement ratio for each are indicated in Table 5.

The agreement ratio for statements 10 is $88,9 \%$ comprising 16 favorable, 2 unfavorable and 4 neuter responses. The favorable responses have underlined such factors as "a very important revenge gained through refined product exports", "restrained supply of refined products in the world", and "the prestige Turkey would receive through a refinery with oil processing capacity". One of the unfavorable responses underlined the redundant capacity of the present refineries.

The agreement ratio for statement 14 is $80 \%$ comprising 16 favorable 4 unfavorable and 2 no-comments responses. Those who have disagreed on the statement have focused on such factors as "Samsun Port will deal with transit shipments only", and "Samsun Port has no adequate hinterland". On the other hand, those who have agreed stated that "Samsun Port is the intersection point of the East-West-North axis", "tanker 
Table 5. The Delphi Statements Agreed on Concerning the Political Effects of the Strategic Developments in the International Energy and Transport Corridors on Turkish Seaborne Trade

\begin{tabular}{|c|l|c|c|c|c|}
\hline \multirow{2}{*}{ No } & Delphi Statements & Distribution* & \multirow{2}{*}{ Results } \\
\cline { 3 - 5 } 10 & $\begin{array}{l}\text { Establishing refineries in the Mediterranean Region with crude oil } \\
\text { processing capacities would make Turkey a key-point in this respect. }\end{array}$ & 16 & 2 & NC & $\begin{array}{c}\text { N 88,9** } \\
\text { I agree }\end{array}$ \\
\hline 14 & $\begin{array}{l}\text { When Samsun-Ceyhan crude oil Pipeline Projects is realized, Samsun Port } \\
\text { would have a strategic importance in terms of energy transport. }\end{array}$ & 16 & 4 & 2 & $\begin{array}{c}\% 80^{* *} \\
\text { I agree }\end{array}$ \\
\hline 5 & $\begin{array}{l}\text { Ceyhan Region, with an important place within the regions; plays an } \\
\text { important role in setting the energy policies of Turkey. }\end{array}$ & 17 & 5 & 0 & $\begin{array}{c}\% 77,3^{* *} \\
\text { I agree }\end{array}$ \\
\hline 13 & $\begin{array}{l}\text { It is possible for Turkey to turn Ceyhan Terminal into an energy center like } \\
\text { Rotterdam Terminal. }\end{array}$ & 15 & 5 & 2 & $\begin{array}{c}\% 75^{* *} \\
\text { I agree }\end{array}$ \\
\hline 12 & $\begin{array}{l}\text { With the further investments in ports and transport infrastructure Turkey } \\
\text { would turn Ceyhan Terminal, an exit gate for energy corridors; into one of } \\
\text { the most important energy centers. }\end{array}$ & 15 & 6 & 1 & $\begin{array}{c}\text { \% } 71,4^{* *} \\
\text { I agree }\end{array}$ \\
\hline
\end{tabular}

Source: Prepared by the author.

* Y-Yes, N-No, NC-No Comments

${ }^{* *}$ The consensus statements.

traffic is likely to grow further", and "despite certain alternatives Samsun port is likely to improve to improve to a further extent".

The agreement ratio for statement 5 is 77,3\% comprising 17 agreements and 5 disagreements. Those who have disagreed seem to have failed to put forward any reasonable views. The points underlined by the panelists could be highlighted as follows "Ceyhan is located at Mediterranean", "relatively low operational costs at Ceyhan terminal particularly for oil and tanker operators", "certain thermic centrals planned to be constructed at Ceyhan region", "Ceyhan's position as an intersection point of the pipelines", and "the likeliness of establishing natural gas and LNG sea terminals at Ceyhan".

The ratio of agreement for statement 13 is $75 \%$ comprising 15 favorable and 5 unfavorable responses. The overall points underlined in the relevant responses could be highlighted as follows; "Ceyhan Terminal at present conditions to be a point of loading only", "investments required for refineries in the region", and "turning the terminal into a production center in addition to the present functions".
The value of agreement gained for statement 12 is $71,4 \%$ with 15 favorable and 6 unfavorable responses. The favorable ones underline such points as "realizing the project for Samsun-Ceyhan Crude Oil Pipeline", "putting stronger stress on state investments", and "energy transfer center". The unlovable responses comprise such points as "turning the crude oil received into products at Ceyhan terminal and distribute the products", "the scale used is too limited", and "lack of certain regulation saving the interests of each transport made in terms of multimodal transport through pipelines".

\subsection{Security/Safety Related Effected}

Three of the four statements offered with respects to the security/safety related effects have received favorable responses. The ones agreed on and the ratio of agreement for each are indicated in Table 6.

The ratio of agreement on statement 7 is $72,7 \%$ comprising 16 favorable and 6 unfavorable responses. Those who have agreed on the statements have underlined such factors as "the probability of marketing the Azerbaijan oil through the Black Sea", "Russia's oil still transported through the 
Table 6.The Delphi Statements Agreed on Concerning the Security/Safety Related Effects of the Strategic Developments in the International Energy and Transport Corridors on Turkish Seaborne Trade

\begin{tabular}{|c|l|c|c|c|c|}
\hline No & Delphi Statements & Distribution* & \multirow{2}{*}{ Results } \\
\cline { 3 - 4 } 7 & $\begin{array}{l}\text { Yhrough Baku-Tiflis-Ceyhan crude oil pipeline, the passage related risks } \\
\text { caused by the excessive (heavy) tanker traffic through the Turkish Straits } \\
\text { are minimized. }\end{array}$ & 16 & 6 & NC & $\begin{array}{c}\text { N } \\
\text { I agree }\end{array}$ \\
\hline 9 & $\begin{array}{l}\text { There is a terror risk in Ceyhan Region in terms of energy supply. } \\
\text { In }\end{array}$ & 5 & 13 & 4 & $\begin{array}{c}\% 72,2^{* *} \\
\text { I don't agree }\end{array}$ \\
\hline 11 & $\begin{array}{l}\text { An increase in the number of the big tonnage tankers being loaded } \\
\text { at Ceyhan Region, increases the risk of the Turkish coasts along the } \\
\text { Mediterranean Sea to get exposed to oil pollution. }\end{array}$ & 14 & 7 & 1 & $\begin{array}{c}\text { \% } 66,7^{* *} \\
\text { I agree }\end{array}$ \\
\hline
\end{tabular}

Source: Prepared by the author.

* Y-Yes, N-No, NC-No Comments

**The consensus statements.

Turkish Straits", "restrained tanker tonnages passing through the Turkish Straits", and "the advantages of Ceyhan Terminal shipments over these through the Turkish Straits in terms of the economies of scale". Those who have disagreed on the state statement have pointed out such views as "marketing the Azerbaijan oil through the Black Sea is not rational in terms of risks, costs and strategic evaluation", "the Azerbaijan oil could be transported through Samsun-Ceyhan Crude Oil Pipeline", and "no noticeable difference between the present oil potential and the amount passing through the Turkish Straits particularly due to certain alternatives emerged".

The ratio of agreement on statement 9 is $72,2 \%$ comprising 5 favorable and 13 unfavorable responses. The former ones underline such points as "the services offered at Ceyhan Region has so far encountered no terror-sourced problems", and "the interferences in providing smooth services have sourced from the political up heals in the origin (Iraq)". One of the panelists who have agreed on the statement pointed out that "though not appeared through media, Iraq-Turkey Crude Oil Pipeline has always been threatened by terror, which is likely to be a matter of concern for Turkey".
The ratio of agreement for statement 11 is $66,7 \%$ comprising 14 agreements and 7 disagreements. The points underlined by those who agree on the statement are as follows; "it is mandatory for tankers operated at the loading ports at Ceyhan Region to be double hulled", "Turkey is late to have been a party in the compensate funds concerning oil pollution", and "the need for increasing the amount of oil pollution prevention equipment". Those who have disagreed on the statement have underlined such points as "the big tonnage tankers, as designed in compliance with the recently adopted conventions, have minimized oil pollution risks", and "the navigation risks at Ceyhan Region are relatively lower".

Meanwhile, no agreement has been reached on statement 16.

\section{Limitations}

The noticeable limitation has been encountered during the content analysis process. The subject of the research is closely related with energy geopolitics which is vulnerable against rapid changes and apt to ongoing changes. Despite such dynamic nature of the subject, the time for content analysis has had be limited and concluded by the end of 2013. The main restraints encountered during the Delphi process has 
been the specific structure of Delphi, policy Delphi, using three-point likert scale and involving only one-tour implementation. Another limitation is concerned with the limited number of statements (19 only) and that of participants (22). The overall ratio of agreement has been accepted as $66,7 \%$ (2/3 majority). The reason why the agreement ratio was so low is that the subject discussed is highly politicsdominated.

\section{Discussion and Conclusion}

The data collected through a literature review and content analysis has been discussed at a qualitative (Delphi) research and certain conclusions have been drawn.

The content analysis reveals such points of significance; "the importance of Turkey in terms of secured energy supply", "Turkey as an energy transit country", and "enriching the variety of energy transit corridors". These points underline the geostrategic importance of Turkey. This importance makes it imperative that Turkey be an undeniable party involved in the strategic developments in the international energy and transport corridors. It is also appreciable that the statements agreed on concerning the economic effects of the strategic developments in the international energy and transport corridors match quite well with the expected effects on shipbuilding industry. Another point to be underlined is that the participants of Delphi process have often used such keywords as "costs", "revenue", and "investments". These keywords are the cornerstones of reaching reliable and sound conclusions. The Delphi statements mostly agreed on could be discussed and implied as follows;

Building powerships (energy ships) with floating electric central is likely to contribute to be improvement of Turkish Shipyard industry. The high ratio of agreement on the statements discuses regarding perfectly matches with the developments recently experienced and supported by the existing built of energy ships and the projects designed for the same purpose.

Crude oil transports through Turkey are less costly than those through the Russian ports along the Black Sea. It is clearly accepted that crude oil transports through pipelines in Turkey reduces costs supported by the fees for passages through the Turkish Straits as well as the waiting periods encountered in winters. The relevant statistics support this view. Besides, a part of Russian crude oil is exported through Baltic ports. Moreover, the decline in the amount of crude oil transport through the Turkish straits could be attributed to some critical sea accidents encountered.

Turkey gains important revenue for her port services during the transport of crude oil from Mid Asia and Mid East to the world markets. Despite a high ratio of agreement gained on this statement, some views put forward by the Delphi participants must be taken into consideration. These are that the revenue gained for port services is only around US \$ 10 million, the relevant operation are under the control of the foreigners, and the Turkish companies are paid very little. All these concerns could be attributed to the weak points overbooked during the bargaining periods for the pipeline projects. All these also demand the fact that the adoption periods of energy strategies and policies are the take into consideration a variety of factors.

Transporting crude oil through the pipelines in Turkey to the world markets has triggered the new investments in Turkish shipping industry. This view is supported by the important developments. Turkish ship-owners; though very few in number, have started to own big tonnage tanker fleet and one of the four shipyards planned at Ceyhan Region has been completed. However, the fact that a great amount of the crude oil transported from 
Ceyhan Region to the world market is carried by Greek ship-owners implies that the Turkish tanker fleet has not matured yet. Turkey based Palmali Group Holding, has recently increased its share in this particular market. And the Turkish owners are expected to enrich their tanker fleet and take a leading role in this business.

Establishing LNG Terminals in Turkey is likely to encourage the Turkish shipping and shipyards industries to get involved in LNG field. It is known that Turkish enterprises have been interested in LNG tanker building and LNG operating industries. The high costs of investment in this industry, however, require state incentives and supports. In fact, this subject must be handled in a national policy involving both private and state efforts in cooperation, and BOTAS's LNG policies could be taken as a fruitful model. The LNG industry promises to be one of the most profitable industries so the steps in this struggle must be accelerated.

Building refineries at the Mediterranean and Region with crude oil processing capacity is likely to take Turkey up to a key point in this concern. In this matter, the very first thing is to thoroughly analysis the existing refineries in Turkey. Despite the prestige it would grant to Turkey, the links required for the crude oil to arrive at the refineries are to be well planned at the first hand. The transport of crude oil from Ceyhan terminals to the world market is, in a sense, a transit type of transport, so a refinery planning for this region is to be questioned. The statistics reveal that the Azerbaijan based crude oil transported to Ceyhan through BTC HPBH is a transit cargo as a whole. Besides, Star Refinery planned to be built at Izmir-Aliaga is expected to get operated in 2014, taking the front row in the relevant struggles.

When Samsun-Ceyhan Crude Oil Pipeline Project is realized, Samsun Port will gain strategic importance in energy transport industry. Though there has been no promising step taken in this matter, this project plays a critical role for Turkey's energy and transport strategies. The project is expected to support turning Ceyhan into an energy center and lessening the traffic though the Turkish straits. Besides, the project is expected to raise the position of Samsun Port in this respect.

Ceyhan takes the very first place with a noticeable value as a strategic importance in Turkey's energy policies. Ceyhan is located at the intersection point of crude oil pipelines, has energy controls in the region based on import coal and hosts on LNG expert terminal project. With these values, 2010-2014 strategic plan of ETKB supports the target of turning Ceyhan Region into an integrated energy center.

It is possible for Turkey to turn Ceyhan Terminal into an energy center like Rotterdam Terminal. The relevant data collected in 2012 reveals that Ceyhan has realized around $13 \%$ of the total cargo handling in Turkey, with a total of 48,5 million tons of oil comprising 32 million tons handled by BOTAS BTC and 16,5 million tons handled by BOTAS Ceyhan Terminal. This amount is quite little compared to a total of 442 million tons (180 million ton of which is oil) handled by Rotterdam Terminal. So the structure of Ceyhan is to cape with that of Rotterdam, which owns a terminal. This requires a serious amount of investments.

With further investments for ports and transport infrastructures, Turkey will turn Ceyhan Terminal, an exit gate for energy corridors, into one of the leading energy centers. This aim looks likely. The handicaps to be overcome however are two fold. First of all, the crude oil reaching at the Ceyhan Terminal is to be processed into products and its distribution is to be arranged. Besides, the internationally adopted agreements concerning pipelines do not have any clauses saving/protecting 
the interests of each made of transport in terms of multimodal transports. This leach is to be overcome.

BTC HPBH helps minimizing the passage risks raised by extensive tanker traffic through the Turkish straits. The mentioned pipelines are thought to minimize the tanker traffic to be passed through the Turkish straits but the main cause of this minimization seems to be that Russia has shifted a part of its oil exports from the Black Sea to the Baltic Ports. Thus, a stronger project to ease the traffic through the Turkish straits is that of Samsun-Ceyhan Crude Oil Pipeline.

The increase in the number of the big tonnage tankers loading at Ceyhan Region raises the risk of oil pollution at the Mediterranean coasts. Though not so high when compared with the other regions, the tankers operated at the Ceyhan Region cause oil pollution. Hence, to prevent such pollution, certain investments and incentives are to be made use of. Besides, in all loading ports in this region, the tankers should have to be double hulled. Furthermore, in order to compensate the losses due to the accidents encountered in this region. Turkey must seek for the means of utilizing the funds used for the oil pollution caused by such accidents.

This study consisting of certain strategic analyses regarding the points likely to affect Turkish seaborne trade is thought to act as a basic for the future studies that will consider and research the energy and seaborne trade related topics together. The overall aim of this explorative, comparative and empirical study is to corridors as well and to gather the relevant perceptions at a common platform. Therefore, further studies supported by statistical data wherein quantitative methods are used are still needed.

\section{References}

[1] Kılıç, A. M. (2006). Turkey's Natural Gas Necessity, Consumption and Future Perspectives. Energy Policy. 34: 1928-1934.

[2] Verma, S. K. (2007). Energy Geopolitics and Iran-Pakistan-India Gas Pipeline. Energy Policy. 35: 3280-3301.

[3] Gnansounou, E. (2008). Assessing the Energy Vulnerability: Case of Industrialised Countries. Energy Policy. 36(10): 3734-3744.

[4] Hacisalihoglu, B. (2008). Turkey's Natural Gas Policy. Energy Policy. 36: 1867-1872.

[5] Sevim, C. (2012). Küresel Enerji Jeopolitiği ve Enerji Güvenliği. Journal of Yasar University. 26(7): 4378-4391.

[6] Umbach, F. (2010). Global Energy Security and the Implications for the EU. Energy Policy. 38: 1229-1240.

[7] EIA (Energy Information Administration). (2011). International Energy Outlook 2011. www.eia.gov/ forecasts/ieo/pdf/0484(2011).pdf (5 Şubat 2012).

[8] Özalp, N. (2004). Büyük Oyunda Hazar Enerji Kaynaklarının Önemi ve Konumu. Panorama Dergisi. Sayı: 1 (Şubat). http://www. panoramadergisi.com/ subat2004/ index.php?dosya=anasayfa. (12 Şubat 2006).

[9] KARKEY (KARADENIZ ENERJİ YATIRIMLARI ENDÜSTRİ VE TİC. A.Ş.). (2010). Environmental Impact Assesment of 231.8 MW Ship/ Barge Mounted Power Generation Project. GEMS (Global Environmental Management Services) Ltd. Korangi Industrial Area, Karachi, Pakistan.

[10] Denzin, N. K. and Lincoln, Y. S. (1994). Handbook of Qualitative Research. Thousand Oaks: SAGE Publications.

[11] Yıldırım, A. and Şimşek, H. (2005). Sosyal Bilimlerde Nitel Araştırma Yöntemleri. Ankara: Seçkin Yayıncılık. 
[12] Facione, P. A. (1990). Critical Thinking: A Statement of Expert Consensus for Purposes of Educational Assessment and Instruction. Executive Summary "The Delphi Report". The Complete American Philosophical Association Delphi Research Report. The California Academic Press.

[13] Dey, I. (1993). Qualitative Data Analysis: A User-friendly Guide for Social Scientists. London and New York: Routledge Taylor \& Francis Group.

[14] Gracht, H. A. (2008). The Future of Logistics: Scenarios for 2025. Wiesbaden: Gabler Edition Wissenschaft.

[15] Linstone, H. A. and Turoff, M. (1975). Introduction. The Delphi Method Techniques and Applications (ss.312). Editors Harold A. Linstone and Murray Turoff. Reading: AddisonWesley Publishing Co.

[16] Şahin, A. E. (2001). Eğitim Araștırmalarında Delphi Tekniği ve Kullanımı. Hacettepe Üniversitesi Eğitim Fakültesi Dergisi. 20: 215-220.

[17] Mitchell, V. W. and McGoldrick P. J. (1994). The role of Geodemographics in Segmenting and Targeting Consumer Markets: A Delphi Study. European Journal of Marketing. 28(5): 54-72.

[18] Mullen, P. M. (2003). Delphi: myths and reality. Journal of Health Organisation and Management. 17(1): 37-52.

[19] Zolingen, S. J. and Klaassen C. A. (2003). Selection Processes in a Delphi study about Key Qualifications in Senior Secondary Vocational Education. Technological Forecasting \& Social Change. 70: 317-340.

[20] Franklin, K. K. and Hart, J. K. (2007). Idea Generation and Exploration: Benefits and Limitations of the Policy Delphi Research Method. Innov High Educ. 31: 237-246.
[21] Pasukeviciute, I. and Roe, M. (2000). The Politics of Oil in Lithuania: Strategies After Transition. Energy Policy. 29(5): 383-397.

[22] Alkan, G. B., Aydoğdu, Y.V. and Yalçın, E. (2014). Türkiye'de Geliștirilmiş Seyir Konsepti Uygulamalarının Delphi Tekniği İle Değerlendirilmesi, Journal of ETA Maritime Science-JEMS, 2014; 2(2): 81-92.

[23] Turoff, M. (1975). The Policy Delphi. The Delphi Method - Techniques and Applications (ss.84-101). Editors Harold A. Linstone and Murray Turoff. Reading: Addison-Wesley Publishing Co.

[24] Gökkuş, Ü. (2013). Boru Hatları Çalıșma Grubu Raporu Sunuș Yazısı. 11. Ulaștırma, Denizcilik ve Haberleşme Şurası. Ankara.

[25] Yüceer, B. and Cerit, A. G. (2001). Caspian Oil Exports and their Impact upon the Tanker Fleet, Developments in Maritime Transport and Logistics in Turkey. Plymouth Studies in Contemporary Shipping and Logistics (ss.118-134). Hampshire: Ashgate Publishing Limited.

[26] Tayfur, F. and Göymen, K. (2002). Decision Making in Turkish Foreign Policy: The Caspian Oil Pipeline Issue. Middle Eastern Studies. 38(2): 101122.

[27] Öztürk, A. (2002). From oil pipelines to oil Straits: the Caspian pipeline politics and environmental protection of the Istanbul and the Canakkale Straits. Journal of Southern Europe and the Balkans. 4(1): 57-74.

[28] Öztürk, H. K. and Hepbaşll, A. (2003). The Place of Natural Gas in Turkey's Energy Sources and Future Perspectives. Energy Sources. 25: 293-307.

[29] Winrow, G. M. (2004). Turkey and the East-West Gas Transportation Corridor. Turkish Studies. 5(2): 23-42. 
[30] Pamir, N. (2004). Bakü-Tiflis-Ceyhan Boruhattı'nda Son Durum. Panorama Dergisi. 3(Nisan): 1-9.

[31] Rabinowitz, P. D., Yusifov, M. Z., Arnoldi, J. ve Hakim, E. (2004). Geology, Oil and Gas Potential, Pipelines, and the Geopolitics of the Caspian Sea Region. Ocean Development \& International Law. 35: 19-40.

[32] Bilgin, M. (2005). Avrasya Enerji Savaşları. 1. Baskı. İstanbul: IQ Kültür Sanat Yayıncılık.

[33] Balat, M. and Özdemir, N. (2005). Turkey's Oil and Natural Gas Pipeline System. Energy Sources. 27: 963-972.

[34] Hirschhausen, C., Meinhart, B. ve Pavel, F. (2005). Transporting Russian Gas to Western Europe -- A Simulation Analysis. Energy Journal. 26(2): 49-68.

[35] Çaha, H. (2005). Asya ve Avrupa'yı Birbirine Bağlayan Enerji Koridorunda Türkiye'nin Yeri. Akademik Araștirmalar Dergisi. 25: 21-36.

[36] Akpınar, E. (2005). Bakü-Tiflis-Ceyhan (BTC) Ham Petrol Boru Hattı ve Türkiye Jeopolitiğine Etkileri. Gazi Eğitim Fakültesi Dergisi. 25(2): 229-248.

[37] Kılıç, A. M. (2005). Major Utilization of Natural Gas in Turkey. Energy Exploration \& Exploitation. 23(2): 125140.

[38] Balat, M. (2006). The Case of BakuTbilisi-Ceyhan Oil pipeline System: A Review. Energy Sources. 1(Part B): 117-126.

[39] Aklin, K. and Atman, S. (2006). Küresel Petrol Stratejilerinin Jeopolitik Açıdan Dünya ve Türkiye Üzerindeki Etkileri. İstanbul: İstanbul Ticaret Odası Yayınları.

[40] Mavrakis, D., Thomaidis, F. and Ntroukas, I. (2006). An assessment of the natural gas supply potential of the south energy corridor from the Caspian Region to the EU. Energy Policy. 34(13): 1-10.
[41] Frankel, E. G. (2006). Challenges and Future Developments in Energy Logistics. IAME Conference Proceedings. Part 19/2. Melbourne. 1214 July 2006.

[42] Laçiner, S. (2006). Hazar Enerji Kaynakları ve Enerji-Siyaset ilişkisi. Orta Asya ve Kafkasya Araştırmaları Dergisi. 1(1): 36-66.

[43] Askari, H. and Taghavi, R. (2006). Iran's Financial Stake in Caspian Oil. British Journal of Middle Eastern Studies. 33(1): 1-18.

[44] Bacık, G. (2006). Turkey and Pipeline Politics. Turkish Studies. 7(2): 293-306.

[45] Barysch, K. (2007). Turkey's Role in European Energy Security. Center For European Reform (CER) Essays. December 2007.

[46] Bilgin, M. (2007). New Prospects in the Political Economy of inner-Caspian Hydrocarbons and Western Energy Corridor through Turkey. Energy Policy. 35: 6383-6394.

[47] Çetin, T. and Oguz, F. (2007). The reform in the Turkish natural gas market: $\mathrm{A}$ critical evaluation. Energy Policy. 35(7): 3856-3867.

[48] Pamir, N. (2007). The Black Sea: A Gateway to Energy Security and Diversification. Southeast European and Black Sea Studies. 7(2): 245-263.

[49] Duru, O. (2007). “Ceyhan” A New Player in Tanker Transportation. Uluslararası Deniz ve Ticaret Dergisi. 2007(Ekim): 42-48.

[50] Murinson, A. (2008). AzerbaijanTurkey-Israel Relations: Energy Factor. Middle East Review of International Affairs. 12(3): 47-64.

[51] Aydal, D. (2009). Enerji Kan Kokuyor: Biyokimyasal Savaş ve Enerji Kartelleri. İstanbul: Timaş Yayınları.

[52] Şen, Y. (2009). Hazar'ın Kanı: Orta Asya'nın Petrolle Yazılan Tarihi. İstanbul: Doğan Egmont Yayıncılık ve Yapımcilık. 
[53] Uğurlu, Ö. (2009). Çevresel Güvenlik ve Türkiye'de Enerji Politikaları. İstanbul: Örgün Yayınevi.

[54] Saldanha, J. and Gray, R. (2002). The Potential for British Coastal Shipping in a Multimodal Chain. Journal of Maritime Policy and Management. 29(1): 77-92.

[55] Rowe, G. and Wright, G. (2001). Expert Opinions in Forecasting: The Role of the Delphi Technique. Principles of Forecasting: A Handbook for Researchers and Practitioners (ss.125144). Editor J. Scott Armstrong. Boston: Kluwer Academic Publishers.

[56] Welty, G. (1972). Problems of Selecting Experts for Delphi Exercises. Academy of Management Journal. 15(1): 121124.

[57] Tersine, R. J., and Riggs, W. E. (1976). The Delphi Technique: A long-range planning tool. Business Horizon, 19(2), 51-56.

[58] Dalkey, N. C. and Helmer, O. (1963). An Experimental Application of the Delphi Method to the Use of Experts. Management Science. 9(3): 458-467.

[59] Yeong, W. Y., Keng K. A. and Leng, T. L. (1989). A Delphi Forecast for the Singapore Tourism Industry: Future Scenario and Marketing Implications. European Journal of Marketing. 23(11): 15-26.

[60] Turoff, M. (1970). The Design of a Policy Delphi. Technological Forecasting and Social Change. 2(2): 149-171.

[61] Mead, D. and Moseley, L. (2001). Considerations in Using the Delphi approach: design, questions and answers. Nurse Researcher. 8(4): 2437.

[62] Bonacina, M., Creti, A. and Sileo, A. (2009). Gas Storage Services and Regulation in Italy: A Delphi Analysis. Energy Policy. 37: 1277-1288.
[63] Saldanha, J. and Gray, R. (2002). The Potential for British Coastal Shipping in a Multimodal Chain. Journal of Maritime Policy and Management. 29(1): 77-92.

[64] Erffmeyer, R. C., Erffmeyer, E. S. and Lane, I. M. (1986). The Delphi Technique: An Empirical Evaluation of the Optimal Number of Rounds. Group \& Organization Studies. 11(1/2): 120128.

[65] Skulmoski, G. J., Hartman, F. T. and Krahn, J. (2007). The Delphi Method for Graduate Research. Journal of Information Technology Education. 6: $1-21$.

[66] KARKEY (KARADENIZ ENERJI YATIRIMLARI ENDÜSTRİ VE TIC. A.Ş.). (2012). Enerji Filomuz. http: / / www.karadenizenergy. com/Pages.aspx? Language $=\& S$ i te $=\& M$ e n u $=$ En er ji F ilomuz\&PageID=133 (22 Kasım 2012). 


\section{Appendix 1-1}

\begin{tabular}{|c|c|c|c|c|c|c|c|c|c|c|c|c|c|c|c|c|c|c|c|}
\hline 氛 & 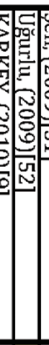 & 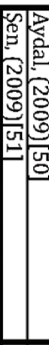 & 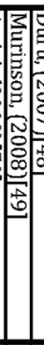 & & 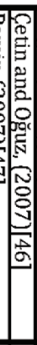 & 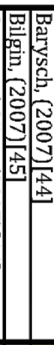 & 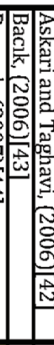 & 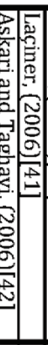 & $\sqrt{0}$ & 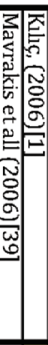 & 图 & 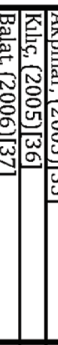 & 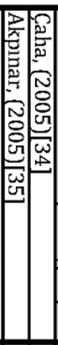 & 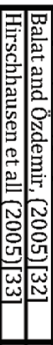 & 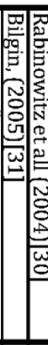 & : & 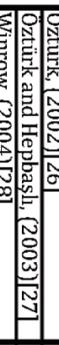 & 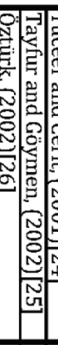 & 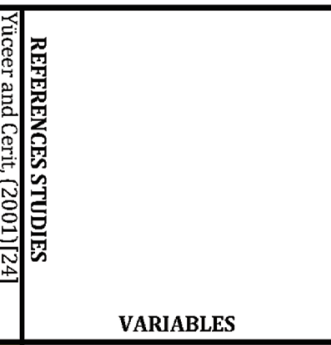 \\
\hline & $x$ & & & & & $x$ & & & & $x$ & & & & & & & & & $\begin{array}{ll}\rtimes & \text { Turkey's key role specified }\end{array}$ \\
\hline$\vec{f}$ & $\times$ & $x$ & & $\star \approx$ & & & & $\star$ & $x$ & & & $x$ & $\star x$ & & $x$ & $x$ & & * & $\begin{array}{l}\text { cheaper and low-risk maritime } \\
\text { transport }\end{array}$ \\
\hline$\sigma$ & & & $\star x$ & ^ & & & & & & & $\star$ & & $x$ & & & × & & & $\begin{array}{l}\text { Safety of navigation in the Turkish } \\
\text { Straits }\end{array}$ \\
\hline$\vec{\Delta}$ & 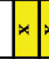 & $x$ & & $\star x$ & & & & $x \times$ & & & $\star$ & & & $x$ & $\star$ & $x$ & & & $\begin{array}{l}\text { × The increase of tanker traffic in the } \\
\text { Turkish Straits }\end{array}$ \\
\hline$\infty$ & & $x$ & & & & & $\times x$ & $x$ & & & $x$ & & & & $x$ & & & \begin{tabular}{c|c|c}
$x$ & $x$ & $x$ \\
\end{tabular} & \begin{tabular}{l|l}
$x$ & The main export pipelines \\
\end{tabular} \\
\hline 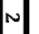 & & & & & & & & & & $x$ & & & & & & & & & $\times$ low cost and high security \\
\hline$v$ & & & & & $\star$ & 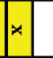 & & & & & & $x$ & & $\star$ & & $\star$ & & $x \times$ & $\times \begin{array}{l}\text { Turkey's strategic location and } \\
\text { importance }\end{array}$ \\
\hline$\infty$ & $x$ & & & & & $x$ & & $\approx$ & & $x$ & $*$ & $x$ & & & & & $x$ & & $\begin{array}{l}\text { Turkey is an energy bridge } \\
\text { between East and West }\end{array}$ \\
\hline$\vec{N}$ & $\approx=$ & $\star$ & & $\star x$ & & & & & & & $x$ & $x \times$ & $\star$ & & $\mp \times$ & $x$ & & $\times x$ & \begin{tabular}{l|l}
$\star$ & The air and the port conditions
\end{tabular} \\
\hline$\infty$ & & $x$ & & * & & & & & & & $x$ & & $\times$ & & $\star$ & $x$ & & * & $\begin{array}{l}\text { specialized to crude oil handling } \\
\text { ports }\end{array}$ \\
\hline 하 & $\approx$ & $\approx$ & & $\star$ & & & & & & & $\times x$ & $\star$ & $\approx x$ & & & $\times$ & & $* x$ & $\begin{array}{l}\text { major energy hub fi } \\
\text { transport }\end{array}$ \\
\hline 0 & $\triangle=$ & 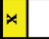 & & $x \times$ & & & & & & & $\star$ & & & & $x \times$ & $x$ & & $\star$ & climate benefits \\
\hline$\omega$ & & & $\star$ & & & & $x$ & & & & & & & & & & & $x$ & Multiple Pipeline \\
\hline • & $x=$ & $x$ & & $\star \approx$ & & & & & & & $\star x$ & & $x$ & & x & * & $x$ & x & $\begin{array}{l}\text { Advantage of the depth of the port } \\
\text { of Ceyhan }\end{array}$ \\
\hline 0 & $x=$ & $x$ & & 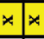 & & & & & & & $\star$ & & $\star$ & & $x$ & $x$ & & $x$ & low loading costs \\
\hline$\omega$ & $\times$ & & & & & $\star$ & & & & & & & & & & & & * & $\begin{array}{l}\text { f tanker accidents in } \\
\text { aits }\end{array}$ \\
\hline v & & & & 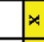 & & $x$ & & & $x$ & & $\star$ & & & & & $x$ & & $x$ & $\begin{array}{ll}\star & \text { cheapest transportation of oil } \\
\end{array}$ \\
\hline $\mathrm{v}$ & & $x$ & & $\star$ & & 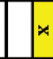 & & $\star$ & & & & $x$ & & & $x$ & & & $x$ & $\begin{array}{l}\text { environmental hazards and } \\
\text { accidents }\end{array}$ \\
\hline 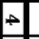 & & & & & $x$ & & & & & $x$ & & $x$ & & & & & $x$ & & Marmara LNG Terminal \\
\hline$\omega$ & & & & & $x$ & & & & & $x$ & & & & & & & 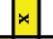 & & use of natural gas for electricity \\
\hline क् & $\star=$ & $x \times$ & $x \times$ & $x \times$ & $x$ & $x x$ & $x x$ & $x$ & & $x$ & $x$ & $x$ & $x$ & & & $x \times$ & & & $\begin{array}{ll}x & \text { Turkey is energy transit country } \\
\end{array}$ \\
\hline$\omega$ & & & & & & & & & & $x$ & & & & $\star$ & & $\star$ & & & East-West gas transport corridor \\
\hline$\theta$ & $\mp=$ & $x$ & & $\star$ & & $x$ & & & & \begin{tabular}{r|r}
$*$ \\
\end{tabular} & & & \begin{tabular}{|l|l|} 
& $\times$ \\
\end{tabular} & $x$ & & $\star$ & & 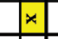 & energy hub / terminal \\
\hline$\sigma$ & $\star$ & $x$ & & & & & & $\star$ & & & & & $\star \approx$ & & & $\approx$ & & & East-West energy corridor \\
\hline$\vec{N}$ & $\star$ & $x \times$ & $x$ & $\star \star x$ & 4 & & & & & $\star x$ & & $x$ & $*$ & & $x$ & $\star$ & & $\star$ & $\begin{array}{l}\text { Ceyhan is an important energy } \\
\text { terminal }\end{array}$ \\
\hline$\pi$ & $\star$ & & & & & $\star x$ & & & & & $*$ & $x$ & & & & $\star$ & & & energy supply security risk \\
\hline 0 & $\mp ;$ & $x$ & & & & $x$ & & & & & $\star$ & $x$ & & & $x \times$ & $\approx$ & & * & $\begin{array}{l}\text { capacity of handling large-tonnage } \\
\text { tankers }\end{array}$ \\
\hline$\pi$ & & & & & $x$ & & & & $x$ & $\star$ & & & & & & * & $x$ & & LNG import terminals \\
\hline 0 & $\mp$ & $\times$ & & $\star \approx$ & & & & $x$ & & & & & $\approx *$ & & $x$ & $x$ & & & $\begin{array}{l}\text { Ceyhan Region is an integrated } \\
\text { energy center }\end{array}$ \\
\hline & & & & & & & & & & & & & & & & & & & powership (energy ship) \\
\hline
\end{tabular}


Appendix 1-2

\begin{tabular}{|c|c|c|c|c|c|c|c|c|c|c|c|c|c|c|c|c|c|c|c|c|c|c|c|}
\hline 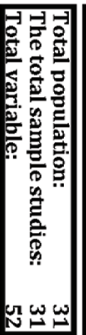 & 图勇 & 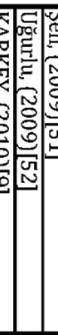 & 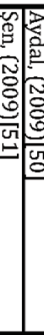 & 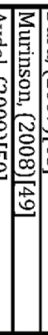 & 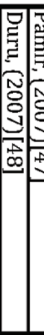 & 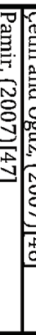 & 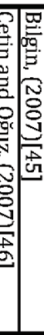 & 递 & 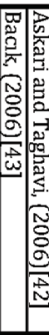 & 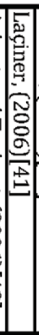 & 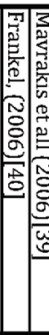 & 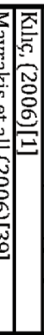 & 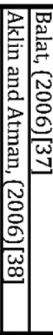 & 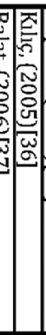 & 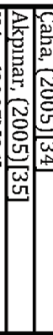 & 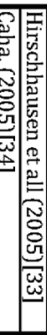 & 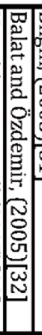 & 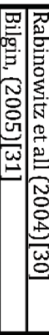 & 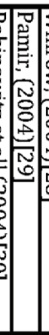 & 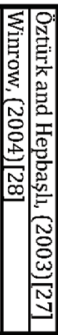 & \begin{tabular}{|c|c} 
\\
\end{tabular} & 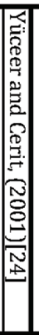 & 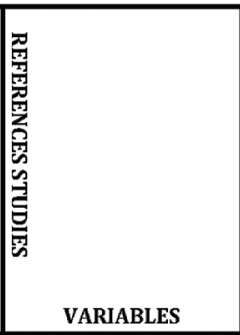 \\
\hline & 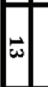 & $\times x$ & $\star$ & & $x$ & & & & & $\star$ & & $x$ & $x$ & & $x$ & & $x$ & $\star x$ & $x$ & & $x$ & $\times$ & $\begin{array}{l}\text { Environmental and safety } \\
\text { concerns in the Turkish } \\
\text { Straits }\end{array}$ \\
\hline & $a$ & & * & & $x$ & & & & & & & & & & & & & $\star x$ & & & $\star$ & $\times$ & $\begin{array}{l}\text { favorable / unfavorable } \\
\text { weather conditions }\end{array}$ \\
\hline & $\infty$ & & & & $x$ & & & $\times x$ & $x$ & & & & $x$ & & * & $x$ & & $\star x$ & & $x$ & & $\star$ & $\begin{array}{l}\text { Proximity to growing } \\
\text { markets in Europe }\end{array}$ \\
\hline & o & $\times x$ & & & & * & & & & & & & $\star x$ & & & & & $x$ & & & & & $\begin{array}{l}\text { the risk of sabotage and } \\
\text { terrorist attacks }\end{array}$ \\
\hline & a & $\times x$ & $\times x$ & 4 & $\times x$ & $\star \times$ & $x \times$ & $\times$ & $\star$ & & $x$ & & $x$ & & $x$ & x & & $\star$ & & $x$ & & & $\begin{array}{l}\text { diversification of energy } \\
\text { transit corridor }\end{array}$ \\
\hline & 0 & & & & $x$ & & $x \times$ & & & & & $x$ & & $x$ & $\star$ & $\star \approx$ & & & & $x x$ & & & $\begin{array}{l}\text { power transmission lines / } \\
\text { energy corridors }\end{array}$ \\
\hline & $\vec{N}$ & $\times x$ & $\star \approx$ & $4 \times$ & $x$ & ^ & & & & & & & $\approx x$ & $x$ & $x$ & & & * & $x$ & & $x$ & & $\begin{array}{l}\text { Ceyhan Terminal is one of } \\
\text { the centers of world oil } \\
\text { markets }\end{array}$ \\
\hline & a & $x$ & $\star x$ & 4 & $\times x$ & × & & & & & & & $\star$ & & $\star$ & & & & & & & & $\begin{array}{l}\text { Samsun-Ceyhan bypass } \\
\text { crude oil pipeline project }\end{array}$ \\
\hline & $\omega$ & $x$ & & & & & & & & & & & $\star$ & & & & & & & & & $\times$ & $\begin{array}{l}\text { that occur in the world oil } \\
\text { market price risk }\end{array}$ \\
\hline & Na & $\neq x$ & $\times \approx$ & & 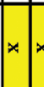 & x & $x$ & $\times$ & $x$ & 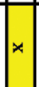 & & $x$ & $\star x$ & $x \times$ & $\approx$ & & $x$ & & 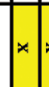 & $x \mid x$ & $\star$ & $\times$ & $\begin{array}{l}\text { Turkey's importance in } \\
\text { terms of security of energy } \\
\text { supply }\end{array}$ \\
\hline & $N$ & & & & & * & & & & & $\star x$ & $x$ & & & & & & & & & & & $\begin{array}{l}\text { North-South energy } \\
\text { corridor }\end{array}$ \\
\hline & $\mid x$ & & & & & & & & & & × & $x$ & & & & & $x$ & $x$ & $x$ & & & & $\begin{array}{l}\text { Lack of proper } \\
\text { infrastructure }\end{array}$ \\
\hline & $N$ & & & & & & & & $x$ & & $x$ & & & & & & & & & & & & $\begin{array}{l}\text { Eastern Mediterranean } \\
\text { energy export terminals }\end{array}$ \\
\hline & $\infty$ & $\star x$ & $x \times$ & 4 & & 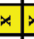 & $x \ldots$ & $x=$ & $x$ & & & & & & & & & & & & 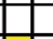 & & Nabucco project \\
\hline & 空 $x$ & & $x$ & $\infty$ & $x$ & & $x$ & & $x$ & $x$ & & & $x$ & $\times$ & $\approx$ & $\approx$ & $x$ & $x$ & & & $x$ & $\star$ & to trigger new investments \\
\hline & $n$ & & * & $4 \times$ & & & & & & & & & & & & & & & & & & & $\begin{array}{l}\text { Israeli-Ceyhan a multi- } \\
\text { purpose pipeline project }\end{array}$ \\
\hline & $\infty$ & $\times x$ & & & $x$ & & & & & & & & $x$ & & & & & $x$ & $x$ & & $x$ & 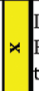 & $\begin{array}{l}\text { Low compared to the } \\
\text { Black Sea port of Ceyhan } \\
\text { terminal handling cost }\end{array}$ \\
\hline & - & $\approx$ & & & & & & & & & & & & & & & & & & & & & $\begin{array}{l}\text { The risk of oil pollution of } \\
\text { the Mediterranean coast of }\end{array}$ \\
\hline & $\vec{N}$ & & * & $\star x$ & $\approx$ & & * & & $\star x$ & $\star$ & & & * & $x$ & $\approx x$ & x & & $\star$ & 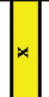 & & $\approx$ & & $\begin{array}{l}\text { BTC crude oil pipeline East. } \\
\text { West energy corridor is } \\
\text { the most critical element }\end{array}$ \\
\hline & $\omega$ & $\times \times=$ & $\star$ & & $\star x$ & × & & $\times x$ & * & & & & $x$ & & $\star x$ & $x$ & & × & & $x$ & & $\times$ & $\begin{array}{l}\text { The role of port during the } \\
\text { transfer energy }\end{array}$ \\
\hline & + & $\mp=$ & $x$ & & $\approx=$ & * & & & & & & & & & & & & & & & & & $\begin{array}{l}\text { The building of a new } \\
\text { crude oil refinery }\end{array}$ \\
\hline & $N \mid \times$ & & & & & & & & & & $x$ & & & & & & & & & & & & $\begin{array}{l}\text { The alternative energy } \\
\text { sources instead of crude } \\
\text { oil and natural gas }\end{array}$ \\
\hline
\end{tabular}

